\title{
Corporatisation, Managerialism and the Death of the University Ideal in Australia
}

\author{
Bede Harris ${ }^{1}$ \\ ${ }^{1}$ School of Accounting and Finance, Charles Sturt University, Albury, Australia \\ Correspondence: Bede Harris, School of Accounting and Finance, Charles Sturt University, P O Box 789, \\ Albury, NSW 2640, Australia. E-mail: beharris@csu.edu.au
}

Received: May 10, 2014 Accepted: May 19, 2014 Online Published: May 28, 2014

doi:10.5539/jpl.v7n2p63 URL: http://dx.doi.org/10.5539/jpl.v7n2p63

\begin{abstract}
The idea of the university as it originated in medieval Europe was that of a self-governing community of teachers and students. However that ideal has been undermined in Australia, where legislative changes over the past 20 years have led to a progressive diminution in university autonomy. Changes to Commonwealth and State legislation mean that universities are now subject to the same internal governance rules as trading corporations, and these are incompatible with the mission of a university and with academic independence. In addition, the regulation of universities has become so invasive that they can no longer be seen as truly autonomous self-accrediting institutions. This article examines the harmful effect of these changes and suggests what changes should be made to the law in order to restore a governance framework for universities which is consistent with their social purpose.
\end{abstract}

Keywords: university, governance, corporations, Australia, academic freedom, managerialism

\section{Introduction}

This article discusses the adverse effects which changes to university governance in Australia over the past 20 years have caused. Part 2 examines the historical development of universities in medieval Europe as self-governing communities of scholars whose primary objective was teaching, research and truth-seeking, and how that traditional model of university autonomy was followed when universities were first established in Australia. Part 3 discusses the relationship between universities and the Commonwealth, State and Territory governments under Australia's federal system, and then discusses the concept of a 'trading or financial corporation', with particular reference to judicial decisions which have characterised universities as trading and financial corporations. Part 4 describes how the governance structures of universities were changed in such a way as to import the duties attaching to corporate officers under the Corporations Act 2001 (Cth), and also discusses why that is incompatible with the mission of a university and with academic independence. Part 5 examines how the Commonwealth has assumed invasive powers over the registration of universities and the accreditation of their courses, to the extent that Australian universities can no longer be considered to be autonomous self-accrediting institutions. Part 6 discusses what changes to the law are required to create a governance framework for universities which is consistent with their social purpose. It also advocates addressing complaints relating to the quality of university teaching as and when they arise, using an Ombudsman with broad jurisdiction relating to tertiary education, in place of the invasive regulation established by the Tertiary Education Quality and Standards Agency Act 2011 (Cth), the underlying philosophy of which appears to be that academics are likely not to discharge their duties to an adequate standard and therefore need constantly to be monitored.

\section{Universities as Independent Scholarly Communities}

In order to critique modern university governance, it is first necessary to explain how the university movement came into being in Medieval Europe, and how the traditional mode of university governance which was established then served to protect the independence of universities in the discharge of their social function. This history of universities is a research field in and of itself, and so only certain key developments can be noted here. (Note 1) 


\subsection{University Autonomy}

The earliest universities in Western Europe were established in Italy and were modelled on cathedral schools, which were ecclesiastical institutions established by prelates to train local clergy. A university performed a parallel function of providing education on secular subjects when students seeking an education, and teachers willing to provide it came together spontaneously, and without authorisation by civil or ecclesiastical authority, (Note 2) to form a school known as a studium generale. (Note 3) The first of these was at Bologna, where a studium was established in 1088. Students from various parts of Europe attended the studium. Conflict often arose between students and the civic authorities, who did not accord non-citizen students the same rights as citizens when matters came before the courts. In an effort to provide themselves with political protection in disputes with the city government, the students formed themselves into guilds - each of which was known as a universitas - representing the various 'nations', or regions of Europe from which they came. Throughout medieval Europe the word universitas referred a defined group of students and / or professors within a studium generale, (Note 4) the entire body of both professors and students being referred to as the universitas magistrorum et scholarium. It was only in the $15^{\text {th }}$ century that the word universitas came to replace studium generale as referring to the institution itself. (Note 5)

The fact that from the earliest stages the students at Bologna found it necessary to assert their rights vis-à-vis the city government illustrates first, that the establishment of what came to be known as a university owed as much to political as to educational factors, and second that universities soon recognised that independence from civil authority was a fundamental requirement if they were to discharge their social function. This led universities to ask secular or spiritual authorities to confer a charter of privileges upon, confirming the universities' right to autonomy. The earliest charter was the Authentica habita, issued by Emperor Frederick I Barbarossa in 1158, which confirmed that students and teachers at the University of Bologna enjoyed immunity from civil courts and could choose to have their cases tried either by the university or by an ecclesiastical court. (Note 6) Similarly, in 1231 Pope Gregory IX issued the bull Parens scientiarum, which confirmed the autonomy of the University of Paris (which had been established in 1160). The universities of Bologna and Paris (along with Oxford, established by dissident teachers from Paris in 1167, and Cambridge, established by teachers from Oxford in 1209) occupy a special place in the university movement in that they were established without a charter but sought one subsequently. Subsequent universities - for example Naples (established by Frederick II in 1224), Toulouse (founded by Gregory IX in 1229) and Rome founded by Innocent IV in 1245) - came into being by virtue of a charter. (Note 7) A further important development in the establishment of institutional autonomy was the recognition of the university as a separate body corporate, capable of owning property, suing and being sued. Although records are imprecise, it is generally thought that the first such recognition occurred at the University of Paris, which by 1200 was recognised as a body corporate with separate juristic personality and which had the right to enact its own internal statutes. (Note 8)

Although it is important to recognise that, during their thousand-year history, universities in Western Europe and in other parts of the world often had to struggle to assert their independence from external control - and indeed lost that struggle during different periods and in different locations (Note 9) - the early history of the university movement nevertheless demonstrates that the most fundamental characteristic of a university was the right to self-government.

Medieval university governance structures varied between institutions but, broadly speaking, early universities adopted either the Bologna or Paris model. At Bologna, the students elected the professors, paid their salaries and did not hesitate to dismiss professors whom they found wanting, (Note 10)although the professors retained control over examinations and the award of degrees. (Note 11) The whole student body was referred to as the 'congregation'. (Note 12) As already discussed, the students were divided into nations. Each nation elected a number of consiliarii (counsellors) who constituted the executive of the university and it was this body of councillors which enacted university statutes. By contrast, at Paris the masters were in control of the institution and students were subject to their discipline. (Note 13) The masters collectively formed the congregation which enacted statutes. (Note 14) Importantly, the fact that the monarch paid the masters' salaries did not affect the right of the former to run the university.

Although the precise degree of influence enjoyed by teachers, graduates and students varied from university to university, the standard structure of university governance throughout Europe involved representatives from some or all of these constituencies in electing a Senate or Council which ran the institution. As will be discussed later, this centuries-old model was remarkably persistent and was still used when universities were established in Australia. 


\subsection{Universities as Self-Accrediting Institutions}

Implied in the concept of institutional autonomy, but worthwhile mentioning separately given its importance, is the concept of the university as a self-accrediting institution - in other words, the idea that the university itself, rather than any external authority, determines what degrees it offers and what their content will be. The right to self-accreditation reflects an acknowledgement that, because of their expertise, the teaching staff of the university are best placed to determine questions relating to academic content. By protecting the right of the university community to determine what it teaches, protection is simultaneously afforded to the freedom of university teachers to advance controversial opinions. For this reason, the concept of self-accreditation is also relevant to academic freedom, which is the next important hallmark of a university to be discussed.

\subsection{Academic Freedom}

Apart from institutional autonomy, the other fundamental requirement of a university has been academic freedom - that is, that academics should be at liberty to express views which might be at odds with political or other authorities. This is necessitated by the historic mission of a university which, along with the obvious mission of teaching, was pithily described by one scholar of university history as 'the pursuit of truth and learning'. (Note 15) Truth-seeking itself required that academics be free to engage in debate - thus it has been stated that 'The right of a professor to follow an argument withersoever it may lead . . . is a claim at least as ancient as Plato'. (Note 16) Progress towards academic freedom was however far slower than was the achievement of institutional autonomy, and was hampered by church control over intellectual inquiry. Thus it was only in the $18^{\text {th }}$ and $19^{\text {th }}$ centuries, following the Enlightenment and the rise of secular universities, that academic freedom was fully secured in Europe. (Note 17)

As to the justification for academic freedom, it is important firstly to recognise that that freedom is just a particular aspect of a broader freedom, namely freedom of expression. Perhaps the most important justification for freedom of expression was that advanced by John Stuart Mill, whose On Liberty (Note 18) contains a defence of freedom of expression based on a sceptical epistemology in terms of which it is argued that freedom of expression ought not to be suppressed because to do so would be to claim infallibility. (Note 19) According to this theory, because it is always possible that truths discovered by human reason are in fact errors which, if one is allowed to challenge them, may be replaced by a new 'truth', (Note 20) even assuming that truth exists (an assertion that is itself open to question), one can never say that one has attained truth. It follows, therefore, that answers to questions about truth are attainable only if there is freedom of thought, expression and inquiry. (Note 21) Furthermore, Mill stated that even assuming one does discover 'the truth' about any particular matter, it does not follow that false statements are without value, as falsity brings about a 'clearer perception and livelier impression of truth, produced by its collision with error'. (Note 22)

Without detracting from the principle that academic freedom is but a specific dimension of freedom of expression, it is clear that, freedom to communicate ideas - which, as we have seen, is the rationale for that broader freedom - assumes a particular importance in academia, given that truth-seeking is part of its university's raison d'etre. For this reason, it is of vital importance to a university in the discharge of its social mission not only that academic freedom be protected but also that the university's governance structures be so constituted as to ensure that that protection is not compromised.

\subsection{Summary Statement on the Nature and Role of a University}

From the historical survey above, one can distil the following statement which defines the nature and role of a university: A university is an autonomous body-corporate, recognised but not controlled by civil authority, which has the authority to accredit its own courses of study. Its social function is to conduct teaching and research in an environment where the freedom to seek truth and publically communicate ideas is protected.

\subsection{Traditional University Governance Structures in Australia}

The governance of Australian universities as first established conformed to the traditional model which owed its origins to the university movement in medieval Europe. Thus s 1 of the University of Sydney Act 1850 (NSW), which established the country's first university, provided that the Senate would initially be appointed by the colony's Governor, acting on the advice of the Legislative Council (that is, the cabinet), but s 6 stated that once the University had graduated more than 100 students, the students would constitute the Senate which would elect the Provost (the equivalent of the Vice-Chancellor in today's universities). Section 8 of the Act defined the powers of the Senate inter alia as to act

...in such manner as shall appear to them to be best calculated to promote the purposes intended by the said University. 
A similar model was established in Victoria by the University of Melbourne Act 1853 (Vic), s 2 of which provided that the initial University Council would be appointed by the Lieutenant Governor, but that once there were 100 graduates of the University, they would constitute a Senate which would thereafter elect the Council.

The traditional model of governance persisted until recent times - for example, s 12 of the University of Adelaide Act 1971 (SA) provided that the Council would consist of the Chancellor and Vice-Chancellor ex officio, five members elected by the Parliament of South Australia and 22 members (an overwhelming majority of the council) elected by the University convocation, which consisted of all graduates, post-graduate students and staff.

This traditional model of university governance was, however, swept away as the result of fundamental and, as is argued below, detrimental changes implemented in the latter part of the $20^{\text {th }}$ century.

\section{Australian Universities and the Federal System}

Before discussing the specifics of legislation applicable to Australian universities, and the ways in which legislation impacts on institutional and individual autonomy, it is necessary to explain the why universities are subject to both State and Commonwealth (that is, federal) legislative power.

\subsection{The Federal System}

In Australia, the Commonwealth of Australia Constitution Act 1901 (UK) (hereafter referred to as the Constitution) distributes legislative authority between the Commonwealth Parliament and the State Parliaments. It does this by conferring stated legislative powers on the Commonwealth Parliament - most of which are listed in s 51 of the Constitution - and leaving residual power to legislate over all other matters to the plenary power of State Parliaments under ss 106 and 107. A few of the Commonwealth's legislative powers are exclusive to the Commonwealth Parliament. The remainder are concurrent, which means that the States may legislate on the matters they relate to, subject to s 109 of the Constitution, which States that any Commonwealth law on those matters will over-ride any inconsistent State legislation. This constitutional structure has had the effect that universities are subject to both State and Commonwealth law.

\subsection{Universities and State and Territory Legislation}

Education is not a Commonwealth legislative power, and so Australian universities are established by enactments of the State and Territory legislatures and are subject to State and Territory legislation regulating their governance. (Note 23) An Act establishing a university typically establishes the university as a separate body corporate and confers on the university's governing body (usually named the Council) powers to govern the institution, including the power to appoint and dismiss staff and acquire and dispose of property. The governing body will also have the power to make internal statutes regulating aspects of university life.

\subsection{Universities and Commonwealth Legislation}

Notwithstanding the fact that the Constitution does not confer a power in relation to education on the Commonwealth Parliament, the Commonwealth exercises significant control over universities by virtue of two of its legislative its powers: the s 96 power to make financial grants to the States on such terms as the Commonwealth sees fit and the s 51(xx) power in relation to corporations.

Because the States are financially dependant on the Commonwealth for over $60 \%$ of their revenue, universities are almost wholly reliant for their income on s 96 financial grants which they, as State institutions, receive from the Commonwealth. The corollary of this is that the Commonwealth is able to exercise a significant degree of influence over universities by attaching conditions to those grants. The principal source of funding for universities derives from the Commonwealth's Higher Education Contribution Scheme (HECS), under which the Commonwealth provides per capita funding per student to the universities, and the students' debt to the Commonwealth is deferred until their income reaches a certain level. The consequence of this is that the number of Commonwealth-funded places that universities can offer depends on Commonwealth budgetary policy. Where universities offer places in excess of these, they do so on the basis that students are liable to the university for the full cost of their studies. In addition to per-capita HECS funding, the Commonwealth also provides ad hoc grants to Universities for specific purposes.

The other constitutional power used by the Commonwealth to regulate universities is the s 51(xx) power, which enables Parliament to enact laws for '...trading or financial corporations formed within the limits of the Commonwealth'. In New South Wales v Commonwealth (Incorporations Case) (1990) 169 CLR 462, the High Court interpreted the word 'formed' as meaning that the s 51(xx) power did not authorise the Commonwealth itself to enact laws for the formation corporations, but rather to regulate corporations once formed under State 
law. However, s 51(xxxvii) allows the Commonwealth to exercise legislative powers which are referred by the States to it, and the States have used this mechanism to confer on the Commonwealth the power to enact laws not only for the operation, but also the formation, of trading and financial corporations, which are now governed by the Corporations Act 2001 (Cth). The corporations power has been given a broad interpretation by the courts, and has been held to include not only the trading and financial activities of corporations but indeed any aspect of corporate activity, the relationships a corporation has with others and the conduct of $3^{\text {rd }}$ parties as it affects corporations. In New South Wales v Commonwealth (Work Choices Case) (2006) 229 CLR 1, the High Court held that the s 51(xx) power authorised the Commonwealth to male laws regulating industrial relations between trading and financial corporations and their employees.

It is important to note that $\mathrm{s} 51(\mathrm{xx})$ empowers the Commonwealth to legislate only with respect to trading and financial corporations, not all bodies corporate. Whether a corporation is a trading or financial corporation is determined by applying two tests - the 'purpose test', formulated in $R v$ Trade Practices Commission; Ex parte St George County Council (1974) 130 CLR 533, in terms of which a corporation will be defined as a trading or financial corporation if it was set up for the purpose of trading or financial activities (even if it has yet to engage in such activities); and the 'activities test', formulated in $R v$ Federal Court of Australia; Ex Parte Western Australia Football League Inc (Adamson's Case) (1979) 143 CLR 190 and Tasmania v Commonwealth (Tasmanian Dams Case) (1983) 158 CLR 1, in terms of which a corporation will be found to be a trading or financial corporation if it engages in trading or financial activities (irrespective of the purpose for which it as formed). In Adamson's Case (at 32) it was held that a corporation would be held to be engaging in trading and financial activities if such activities formed a 'substantial' part of its activities, and in the Tasmanian Dams case, the court held (at 156) that a corporation could be considered to be a trading or financial corporation even if such activities were not its primary or dominant activity.

Although it might not be thought that universities are trading or financial corporations, in Quickenden $v$ O'Connor (2001) 184 ALR 260 the Full Court of the Federal Court held that the University of Western Australia was a trading corporation, because it earned significant income from the sale of publications, the charging of fees to full-fee-paying overseas students, the provision of accommodation and also from the management of the University's property and cash portfolio. The court reached this conclusion despite acknowledging that trading was not the primary purpose of the university, and that the University earned only $18 \%$ of its income from trading activities. The result of the Quickenden case was therefore to affirm the legal principle that universities are trading and financial corporations and are therefore subject to laws enacted under the s 51(xx) power. This decision gave the Commonwealth an additional, and more direct, avenue than that provided by conditional grants under s 96 to regulate universities and, as will be shown, it has used this power extensively.

\section{Changes to University Governance and the Erosion of Institutional Independence}

In recent years, universities have faced threats to institutional autonomy and to individual academic freedom as a result of the exercise of both State and Commonwealth legislative power. This part of the article examines how this has occurred.

\subsection{Changes to University Governance Structures from 2003}

As stated in Part 3.2 above, a State or Territory Act establishing a university will confer the power to govern the university on a Council. It is in relation to the composition of their governing bodies that the autonomy of universities has been significantly eroded. For, in contrast to the traditional model where a university was governed by a body that was either wholly or predominantly elected by academic staff and students, none of the university governing bodies in Australia is now elected in that way. It is currently the norm that a majority of members will be external to the university and that a substantial number - in some cases a majority - of them will be government appointees.

Although it is the States and Territories which have legislative responsibility for universities, the shift in structure of university councils occurred at the behest of the federal government, which used the lever provided to it by the fact that, as stated earlier, the States and Territories lack the resources to fund universities, which are therefore dependant on federal grants for their operation. The seeds of the changes to university governance structures were laid in the Dawkins Report of 1988 (Note 24) into Australia' tertiary sector, commissioned by the Commonwealth government. In the report the following was stated with regard to university management bodies: (Note 25)

On the other hand, there are some governing bodies which are too large for effective governance, and too often a tendency for members of governing bodies to see their primary role as advocates for particular interests. Often in these cases there is a confusion of roles and objectives, to the detriment of 
strong and decisive management. While some members may feel responsibility to represent the views of particular sections of the institution or the wider community from which they are drawn, they have an overriding responsibility to act in the best interests of the institution.

The report also recommended that the consent of university councils should no longer be required (as it then was) for the dismissal of academic staff, on the ground that such issues were adequately addressed by industrial relations law. (Note 26)

The next report on tertiary education was the Report of the Higher Education Management Review Committee, known as the Hoare Report, commissioned by the Commonwealth in 1995.(Note 27) The report alleged that there were shortcomings in the governance systems of Australian universities which made them unable to operate in a competitive environment and lacked a 'strategic focus'. (Note 28) The report characterised as a negative feature the fact that attendance levels at university council meetings was higher for staff and student representatives than for external members, (Note 29) and that internal members tended to speak most often with the alleged result that external members felt marginalised (Note 30) - factors which are surely explained on the basis that members of an institution are naturally more interested and involved in its affairs than are externals. In order to remedy these perceived flaws in university governance, the report recommended that a majority of university council members should be external to the university and should be government appointees. (Note 31) Although the report also recommended that a university should have a Senate which was separate from the Council, and which would have the task of preserving academic independence, it critically did not take the step of recommending that that body should be able to veto the council either in general or in specific circumstances.

These recommendations ultimately came to be put in legislative form following the publication of a report by then Commonwealth Education Minister, Brendan Nelson in 2003. The Nelson Report (Note 32) made the assertion that (Note 33)

Universities are not businesses but nevertheless manage multi-million dollar budgets. As such they need to be run in a business-like fashion.

It also stated that what it described as 'anachronistic governance arrangements' (Note 34) were no longer suitable. The report further stated that university council members should act in the best interests of the university as a whole, rather than in the interests of the constituency to which they owed their election or appointment, and that a majority of council members should be external to the university. (Note 35) The report contained a set of National Governance Protocols for Public Higher Education Institutions, (Note 36) compliance with which was ensured by the Commonwealth's use of its grants power. The Commonwealth implemented the Nelson Report by enacting the Higher Education Support Act 2003 (Cth), which tied funding to universities to their compliance with the National Governance Protocols, State and Territory governments were required to put them into legislative form if universities in their respective jurisdictions were to receive Commonwealth funding for universities and universities in turn were required to implement them in order to receive funding. (Note 37)

Most significant of the protocols was Protocol 3, which required that members of university councils be affixed with certain duties, phrased those duties using almost verbatim the same language as is used in the Corporations Act 2001 (Cth) to define the duties of directors of corporations. The Corporations Act 2001(Cth) imposes on directors of corporations duties to act with due care and diligence (s 180), to act in the best interests of the corporation and for proper purpose (s 181) and not to use their position as a director or information gained from it to harm the company or to make a gain for themselves or someone-else - essentially, a duty to avoid conflicts of interests (ss 182-183).

In addition, Protocol 5 required that there be a majority of 'external independent members' on university governing bodies - the irony in the juxtaposition of the words 'independent' (which, in the context of university autonomy requires freedom from outside control) and 'external' no doubt being unintended.

Nowhere in any of these reports spanning the years 1988-2003 was any justification advanced as to why the fact that universities controlled significant resources - which had of course always been the case - necessarily indicated that they should be required to adopt a different form of governance. Nor, more specifically, was it stated why governance models used by commercial corporations were appropriate for universities, whose raison d'etre is completely different. One theory is that the imposition of the corporate model was a result of the adoption by government of neo-liberal economic theory in terms of which universities were to be seen as enterprises selling a service (education) in competition with each other. (Note 38) Musselin $(2005,70)$ identified a more sinister agenda behind the changes, saying that their intention was 'to develop executive leadership and to weaken deliberative bodies and collegial decision-making'. (Note 39) As will be shown later in this article, this bleak analysis would subsequently be shown to be accurate. 
Although governance structures vary somewhat from jurisdiction to jurisdiction, all are consistent with the National Governance Protocols. Broadly speaking the following models can be identified: In New South Wales, Tasmania, Queensland and Western Australia, legislation typically provides that a university council will consist of a mixture of members drawn from four categories: ex officio members, (Note 40) members appointed by the government, members elected by staff, students and graduates and members appointed by the council itself. The legislation may also provide that a majority of members may not be drawn from any one of these categories, and it may also provide that a majority of members must be people who are external to the university (in other words, who are not staff or students). (Note 41) In Victoria, staff and students have no representation at all on university councils, and membership consists of ex officio members, council-appointed members and government-appointed members - the last being at least equal in number to the council-appointed members. (Note 42) Government influence is even more pronounced in the ACT and Northern Territory, where although staff members elect some council members, the legislation allocates a majority of positions to government appointees. (Note 43) Only in South Australia are university councils free of government nominees, being comprised of ex officio members, external members appointed by the council itself and members elected by staff and students. (Note 44) The University of Adelaide provides for the highest proportion of council members elected by staff, students and graduates, with ten out of the 21 places on the council being filled by them. (Note 45)

As Thornton states, (Note 46) the consequences of these changes have been that

The pruning of university councils and their primary stakeholders means that there are now likely to be few councillors who are au fait with academic issues. To drive the point home, the new federal protocols specify that there must be a majority of external independent members. The intimate knowledge of the academic enterprise that an academic might be expected to have is now construed as tantamount to a conflict of interests. According to the new governance protocols, one member should have 'substantial business experience'. However, there is already a preference for business appointees to the councils of public universities, a trend that has been induced by the prevailing climate of entrepreneurialism. It is business knowledge that has supplanted academic knowledge, a factor that can only distort the idea of the university with its commitment to reason, culture and excellence

Collegial forms of governance are deemed to be cumbrous and old-fashioned by the new-style university managers. They would prefer to make executive decisions unilaterally and short-circuit consultative processes. Not only does this save time, it obviates the need to deal with the discomfiting side of democracy - dissent. The same point can be made about faculty and school meetings and the preference for executive decision-making by deans and heads.

The overall picture which emerges is that universities are no longer autonomous in the sense of being governed by bodies which are elected by the members of the university community. Furthermore, even though the Labor government elected in 2007 enacted the Higher Education Support Amendment (Removal of the Higher Education Workplace Relations Requirements and National Governance Protocols Requirements and Other Matters) Act 2008 (Cth), which repealed those provisions of the Higher Education Support Act 2003 (Cth) which had tied compliance with the National Protocols as a condition for the receipt of Commonwealth funding, none of the States or Territories amended their University Acts so as to revert to pre-2003 governance structures, and so the institutional changes implemented in 2003 remained in place. Furthermore, given that a new power-structure became dominant in the universities after 2003, it is understandable that those who benefited from it should not have sought a reversion to the status quo ante - indeed in 2011 Universities Australia (the national representative body for Australian universities) and the University Chancellors Council published a document entitled Voluntary Code of Best Practice for the Governance of Australian Universities, which recommends continuance of the existing model. (Note 47).

\subsection{The Impact of Governance Changes on University Management}

The increasing dominance by external members, a significant proportion of whom are government appointees, means that councils are increasingly distant from the communities they govern. The attitude of a council member who is external to the university will be different to one who is part of the university community and who owes his or her place to election by members of that community. There is an almost inevitable tendency for a 'them' and 'us' mentality to come into being, with the external members seeing their role - and indeed the role of the council - as being that of a watchdog over the university community rather than as being responsive to it. Of course university councils have always had an oversight role, but there is an undeniable and significant difference between oversight by a collegial and democratic body elected by the community it regulates, and one 
populated predominantly by appointed members who have no attachment to the university other than their holding of a position on its council.

The new system of governance also had significant negative implications for the relationship between university staff and management. Under the traditional model, university managers were ultimately answerable to the university community because they (the managers) were appointed through processes controlled by, and exercised their powers subject to, a council elected by that community. This meant that, in exercising their functions, managers were responsive to that community. This was particularly so in cases where managers were drawn from the ranks of the academic staff, to which they would return after their term of managerial service ended. Now, however, managers owe their continuance in office to satisfying performance norms set by a corporatized council rather than to acting in a collegial manner towards the academic staff. As was stated by Thornton (Note 48)

It is in response to the market turn that universities have been corporatised which has resulted in the inversion of the traditional norms of governance. Instead of collegiality, in which decisions were made by the academic community as a whole, we now have a system of top-down managerialism whereby university decision-making has become the prerogative of administrators, government officials and business representatives.

This change in role has also been reflected in changes to nomenclature. As is stated by Weinberg and Graham-Smith (Note 49)

Ancient university positions, offices, bodies, though honoured by time, have been renamed to reflect their new alignment with the marketplace, politically overlaid in turn by way of state dictates. Thus, in many universities worldwide..., we have 'executive dean'; 'senate executive committee', 'faculty executive', 'faculty or college board'; heads of schools and institutes who had previously retained their professorial designations (as befits the academy) are now 'executive directors', the inscripted stylisation marking a deliberate and unambiguous shift in allegiance from collegiate to administration (executors of educational policy).

The same is also now true in respect of senior academic staff - heads of departments, schools and faculties who formerly gave their loyalty to those below rather than above them in the university hierarchy and to whose ranks they usually returned. (Note 50) Nowadays the incumbents of these positions are appointed by means of a management-controlled process, and therefore owe their continuance in office to satisfying performance norms set by managers rather than to acting in a collegial manner towards their staff. As is stated by Weinberg and Graham Smith (Note 51)

Senior university representatives have reclassified themselves as 'executive' or 'top management', and their authority scaled down into the system at every level, such that the chair of department functions as a line manager answerable to superiors, thus removed, technically speaking at least, from the department he or she serves.

Because managers are appointed by, and are responsible to, a council dominated by outsiders, they (the managers) have no particular reason to act in a manner that has the support of the university community. Indeed, the incentive is the opposite, with managers striving to satisfy the demands of a council which operates with the mindset of a corporate board, not that of a collegial academic body. This is reflected in matters both major and trivial - an example of the latter being the use of grating corporatist language, such as referring to the 'brand' of a university, as though a university is an institution that peddles soap-powder.

More important, however, is the fact that the power relationship between management and academic staff is now the reverse of what it was, to the extent that the predominant experience in Australian universities is that collegial culture has been replaced by a managerialist one, under which university managers see themselves as the masters, rather than as the servants, of the university community. The fact that managers now dictate to staff in furtherance of corporatised objectives, rather than acting as their assistants in implementing communal objectives, has meant that management has become increasingly alienated from staff, to the detriment of the institutions they manage.

The consequences of this were starkly demonstrated by the case of Allan Patience, a Professor of Political Science at what was then the Victoria University of Technology, who was himself a member of council elected by the academic staff. (Note 52) After criticising proposed allocations of University resources, including the expenditure of $\$ 100000$ on a corporate box at a sports stadium - at a time when the University was cutting back on its internal mail service and funding for research - Patience's access to the University email system was cut 
off on the ground that his criticism of the university was defamatory (Note 53) - although the University subsequently declined to explain the basis for this allegation. (Note 54) What is striking about this case is not only the assault on academic freedom, but also the fact that because elected members of the University council were in a minority, Patience's position on the council afforded him no protection.

\subsection{The Incompatibility between the Duty to Act in the Best Interests of the University and Academic Independence}

The potential for university councils to act contrary to the interests of the academic communities they govern is increased by the fact that, as stated above, State and Territory University Acts impose on council members the same duties as apply to directors of corporations. (Note 55) On the face of it, the imposition of these duties may seem innocuous, even laudable. However there is, paradoxically, potential for conflict between the historical social functions of a university on the one hand, primary among which, as discussed in Part 2, is truth-seeking, and the duty to act in the best interests of the university on the other, which mirrors s 181 of the Corporations Act 2001 (Cth).

Why the imposition of a duty to act in the best interests of the university is problematic is because although it might be thought that to act in the best interests of the university will coincide with acting in the best interests of truth-seeking, that will not always be the case. It may well be that the activity of a member of the university community, while consistent with truth-seeking, may cause harm to the university by exposing it to political controversy, and so it could be argued that in such circumstances, the broader interests of the university are served by suppressing, rather than defending, such activity. This argument is supported by case authority, such as that provided by Hutton $v$ West Cork Railway Co (1883) 23 Ch D 654 and Re George Newman \& Co [1985] 1 $\mathrm{Ch} 674$, to the effect that whereas profit-making is the primary objective of a corporation, the directors of a corporation act consistently with their duty to act in the best interests of the corporation even if they deploy corporate assets to non-profit-making activities - such as political donations - because of the ancillary benefits that may accrue to the corporation in the form of enhanced public image or favourable treatment by the government. If the same reasoning was adopted in the case of a university, it could be said that although the primary function of a university is the search for truth and its dissemination, the Council's duty to act in the best interests of the university could justify (indeed, could require) it to act contrary to truth-seeking in circumstances where that was necessary in order to protect the university's political position. (Note 56) Here it is worthwhile recalling that, as discussed in Part 2.5 above, s 8 of the original University of Sydney Act 1850 (NSW) stated that the duty of the University's governing body was to act 'in such manner as shall appear to them to be best calculated to promote the purposes intended by the said University' (emphasis added) - not to act in the best interests of the University, which is a subtle but crucial difference.

A notable example of such a conflict arising was at James Cook University during the late 1990's, when David Haigh, an environmentalist and academic, who was on the staff of the Law School, made public comments in support of a campaign to prevent development of a natural heritage area at Hinchinbrook Island off the coast of Queensland which, based on his area of expertise, he considered to be harmful to the environment. This activity pitted Haigh and others against a local property developer, Keith Williams, who had the support of the State government. The University, wishing not to antagonise Williams (a prominent local businessman in the region where the University is situated) or the government, prohibited Haigh from making public statements on environmental matters unless such statements were first cleared by the Head of School. The university subsequently initiated disciplinary action against Haigh for alleged misuse of University resources for sending emails criticising the development, despite the fact that not only did his comments fell squarely within his area of expertise as an environmental lawyer but they also constituted community engagement which formed part of his duties as an academic. (Note 57) The university's action illustrates how academic freedom is put at risk when the duties of university councillors - and in particular the duty to act in the best interests of the institution - are framed in terms drawn from corporations law. (Note 58)

\section{Commonwealth Grants as a Mechanism for Control of Universities}

The past two decades have seen the Commonwealth use its legislative power over universities in such a way as to intrude to an increasing degree in university operational matters. In contrast to the changes to university governance structures which were achieved by attaching conditions to university grants under s 96 of the Constitution, the Commonwealth's regulation of university operations has been achieved using its s 51(xx) power to enact laws for corporations. This the Commonwealth is able to do because, as explained in Part 3.3 above, the court in Quickenden v O'Connor (2001) 184 ALR 260 found that universities are trading and financial corporations, and were thus subject to laws enacted under s 51(xx). 


\subsection{The Commonwealth's Regulatory Scheme}

Hand in hand with the changes to university governance implemented since 2003, the Commonwealth government has, under the guise of 'quality assurance' established a regulatory regime which has given it control over the most detailed aspects of university operations.

The first agency used by the Commonwealth to regulate universities was the Australian Universities Quality Agency (AUQA), established in 2001. The role of AUQA was to conduct 'quality audits' of all tertiary institutions. It had no role in relation to accreditation. Universities which owed their existence as self-accrediting to State and Territory legislation retained that status indefinitely. Non-university institutions had to seek accreditation of their courses from their State or Territory government. Although compliance with the AUQA regime was administratively burdensome and amounted to an intrusion into university autonomy, it at least had the saving grace that AUQA audited an institution with a view to determining the extent to which that institution was meeting its own objectives - it was not a case of AUQA auditing the institution for compliance with externally-imposed criteria.

The level of governmental intrusion into university affairs under AUQA was nothing compared to what happened in the wake of the publication of the report of the Review of Australian Higher Education (known as the Bradley Review) in 2008. (Note 59) Indeed, the Bradley Review proved to be the hammer that drove the final nail into the coffin of university autonomy in Australia. As in the case of the Dawkins, Hoare and Nelson reports, the Bradley Review based its recommendations on generalised non sequiturs such as that the provision of education in a 'larger, more diverse, demand-driven system' necessitated increased regulation, (Note 60) and that existing mechanisms for quality control over university education were inadequate, notwithstanding the existence of AUQA - it being an unstated assumption that universities could not be trusted to maintain standards themselves, despite having done so for more than a century in Australia, and for centuries before that overseas. The Bradley Review recommended the establishment of a national regulatory body which would accredit all tertiary education providers (such accreditation being valid for no longer than 10 years) and which would also have responsibility for more comprehensive quality audits than those which were being conducted by AUQA. (Note 61)

The government accepted the recommendations of the Bradley Review. AUQA was replaced by the Tertiary Education Quality and Standards Agency (TEQSA), which was established by the Tertiary Education Quality and Standards Agency Act 2011 (Cth) (hereafter referred to as the TEQSA Act), which was given the power to register higher education providers and to accredit the courses they offered. The general functions of TEQSA as stated in s 134 of the Act are very broad, and include the power to conduct compliance and quality assessments and to conduct accreditation assessments of courses. Universities which existed under State or Territory law were deemed to be registered higher education providers under s 2 of Schedule 3 of the Tertiary Education Quality and Standards Agency (Consequential Amendments and Transitional Provisions) Act 2011 (Cth) for a period specified in relation to each institution in that section, and under s 12 of the Schedule, such institutions as were self-accrediting under State or Territory law were considered to be self-accrediting under Commonwealth law. Thereafter, however, those institutions became bound by the requirement contained in s 35 of the TEQSA Act to seek renewal of registration for a maximum of seven years which, under s 36(1) TEQSA would decide whether to grant or not depending on the institution's compliance with the Threshold Standards (discussed below). Similarly, although s 45(1) of the TEQSA Act states that institutions that were authorised to self-accredit courses before the Act came into force retain that power, s 45(2) as read with 32 empowers TEQSA either to impose conditions on an institution's entitlement to self-accredit or to remove such power. Section 101(1) empowers the Minister to cancel the registration of a provider for non-compliance with the Act, including breaching the Threshold Standards, as provided under s 98(a). Section 99(a) also empowers the Minister to cancel the accreditation of a course of study offered by a provider. Therefore, although the concepts of institutional independence self accreditation are superficially preserved, the reality is that both the continuing existence of universities and their right to self-accreditation are now dependant upon the pleasure of the Commonwealth government.

Critical to the operation of the TEQSA Act are the Threshold Standards. Under s 58 of the Act, the Minister is empowered to issue standards with which higher education providers are required to comply: The Higher Education Standards Framework (Threshold Standards) 2011 (Cth) were issued in 2011. Section 59 of the Act empowers TEQSA to investigate any aspect of a provider's operations in order to determine whether it is compliant with the Threshold Standards. In furtherance of this function, TEQSA has extensive powers of entry, search and seizure under ss 70-72, and under s 63 may compel any person connected to a higher education institution to provide TEQSA with information, failure to do so being a criminal offence under s 64. Perhaps one 
of the most telling aspects of the Act is the fact that although the Bradley Review paid lip-service to academic freedom as a principle underlying tertiary education, (Note 62) none of the coercive machinery in the TEQSA Act was directed to supporting that principle or providing a remedy or sanctions if it was breached.

It is clear from the above that compliance with the Threshold Standards is critical to a university's continued registration as a higher education provider and the continued accreditation of the courses it offers. The Standards are broadly-phrased and impose requirements in relation to virtually every aspect of a tertiary institution's operations. Chapter 1 contains prescriptions relating to governance structures, such as that a majority of a provider's governing body consist of external members. Chapter 3 requires institutions to meet Provider Course Accreditation Standards, which themselves contain requirements relating to course design, admission criteria and matters relating to teaching and assessment. Chapter 4 imposes more detailed standards relating to courses by requiring that courses at different levels meet criteria prescribed by yet another set of standards - those set by the Australian Qualifications Framework (AQF), which attempt to capture in words the difference between 10 levels of qualification, ranging from Certificate to Doctorate. (Note 63) These requirements are phrased in verbose jargon, which fails to conceal that ultimately the difference between different levels of study - at least in the case of coursework qualifications - essentially boils down to how advanced the content is, which universities have long been able to determine.

The existence of the heavy-handed regulatory regime created by the TEQSA Act in response to the Bradley Review is all the more surprising given the emphasis which the Nelson Report had placed on the need for universities to be treated as businesses operating in a free market, which led to the governance changes discussed in Part 4.1 above. The contradiction between these two strands of Commonwealth policy is discussed further in Part 6.

\subsection{The De-professionalisation of the Academic Career}

This regulatory framework has had significant adverse consequences. The most obvious of these is that although the pretence is maintained that universities retain their independence, the reality is that both their existence and their control over what they teach have become conditional in that the Commonwealth government, acting through TEQSA, can remove registration (which is granted for periods of no longer than seven years) and accreditation. If the very existence of universities is held hostage to the satisfaction of a bureaucratic agency, how can it be maintained that they are truly autonomous?

Equally alarming is the extent of the intervention in day to day university activities enabled by the Threshold Standards because of their level of detail. All the matters to which they relate - course structure, admission criteria, assessment standards, teaching, assessment and the standards for various types of qualification - are quintessentially ones lying at the core of a university's activities, which universities are therefore best placed to determine. The regulatory regime established by TEQSA and the AQF smacks of mistrust in the ability of academics to discharge their role in a proper manner. The result of this is that academic staff have become both de-professionalised and infantilised, in that they are no longer trusted to exercise independent professional judgment and are deemed to need constant supervision. The academic career is no longer a 'profession' in the sense that that is understood in relation, for example, to medical or legal practitioners, who are assumed on an indefinite basis to be competent to determine their mode of practice according to their own judgement, and who can be removed from practice only if specific professional wrongdoing is proved. The regulatory framework governing universities operates on the reverse presumption - that institutions and the academics who work in them should be under constant obligation to prove their competence to an external authority, should not be allowed the discretion to determine how they practise and should instead discharge their role in a manner dictated by that authority. As Weinberg and Graham-Smith state (Note 64)

Formerly self-empowered as a practitioner of knowledge and an authority in the discipline, and in the running of the university, the practising academic has been relegated to the role of mere functionary in a system whose core principles are essentially uncollegial. The driver of the institution of learning has become the least significant player.

The need to comply with TEQSA and the AQF has required universities to erect internal 'quality assurance' bureaucracies of Byzantine complexity. A large proportion of an academic's working life is now spent in compliance activities, principally creating documentary evidence that they are doing their jobs in a manner that will satisfy external audit by TEQSA. In many instances this involves the academic asserting truisms - for example, that 'assessments are appropriate for the subject' - a statement which of course ultimately depends on the academic knowing how to assess, which he or she should not have been appointed to teach unless he or she knew how to assess - and which he or she ought therefore be trusted to do. (Note 65) The entire process becomes 
so burdensome in terms of time and frustration that it arguably hinders true quality improvement because it absorbs time academics would otherwise spend on developing their teaching and engaging in research.

\subsection{The Commodification of Research}

Corporatisation, managerialism and intrusive regulation have also had adverse consequences for research. In keeping with the idea of a university as a business producing 'outputs', research has become commodified, as Weinberg and Graham-Smith state (Note 66) 'The market is indifferent to the intrinsic merit of a cultural product - it is interested only in its monetary worth.' Universities now have Deputy or Pro-Vice Chancellors of Research, and Faculties and Schools have Deputy or Associate Deans of Research or 'Research Managers', who are not, as might be thought, the pre-eminent researchers in an institution. Indeed, they are likely to do no research at all. Rather their function is to direct the academics who are actually conducting research. No longer is research a matter of the academic entering autonomously into whatever field of research takes his or her fancy. Instead, universities now identify 'fields of research excellence' or 'areas of research strength' to which staff are instructed to direct their energies, irrespective of their own interests and talents. This is because in the era of commodification, research is valued for the income it brings to a university in the form of grants, and the potential for grants is maximised if everyone's research efforts are concentrated in the same area. As Saunders states (Note 67)

..universities are now incomparably more concerned with research money than with research per se. Whereas money was once considered one of several prerequisites for research, the means have now become the ends. Money is not pursued to allow research, research is pursued to attract and acquire money. Managers, who might do little or no research of their own, have in many places become almost insistent that the only research done under their auspices is that which generates money, either in the form of the research grant or, to a far lesser extent, the Department of Education, Science and Training-approved or "audited" publication.

It does not matter to them that in many disciplines research might require a lot of time but only a little money. In fact, those who are able to do a lot with very little are barely tolerated. The more commercially-minded managers - and they are on the increase - want research which requires and generates money, not that which can done cheaply

This line of thinking has had bizarre consequences, in that if there were academics in the same discipline in two universities, each writing the same set of articles, but the academics in University A successfully applied for a grant from the Australian Research Council (ARC) to write the articles while those in University B simply wrote the articles, those in University A would without doubt be seen as better researchers because their research had cost money (Note 68) - as well as costing the time it took to write the grant application and go through the tortuous approvals process. Indeed, in some instances, a project might well be completed by group B in the time it took group A to obtain their grant. Furthermore, in many instances researchers in the humanities (and here the difference between humanities and sciences needs to be recognised) do not need money to conduct research, but simply time and access to a library. A colossal amount of time is wasted in drafting and submitting ARC grant applications - only $22 \%$ of which are successful (Note 69) - yet applying for a research grant is becoming the sine qua non of satisfying academic managers that one is engaged in research. The focus on grant applications has also had a distorting effect on the type of research that is conducted, because the ARC directs funds almost exclusively to teams, not individuals, and accords substantial weight to track record in the research area, which means that the individual researcher who has a novel idea and is breaking into a new area of endeavour has little chance of success - yet that is surely the type of research that should be encouraged. (Note 70)

Grant applications aside, an academic's research performance is nowadays determined with reference to journal rankings. Whereas 30 years ago the author of the leading student text in his or her field would have earned prestige, today textbooks are not counted at all as research activity under the Commonwealth's Higher Education Research Data (HERDC) collection system, (Note 71) which is used to determine allocations under Research Infrastructure Block Grant (RIBG) scheme, (Note 72) in terms of which universities receive an amount of money per publication by their academic staff. This omission is justified on the basis that textbooks are a re-statement of knowledge rather than constituting new knowledge - despite the fact that the hallmark of a good textbook is that it should offer novel understandings, novel insights and novel taxonomies, features which are quite obviously indicators of an original contribution to knowledge. Nowadays, if textbooks count at all towards an academic's performance they do so under teaching, but even here the overwhelming experience of academics is that performance in teaching depends almost entirely on achieving positive student survey responses. 
Finally, when research productivity is measured, the focus is not on what the academic has written, but the ranking of the journals in which research was published. In 2010 the ARC published a set of journal rankings as part of its Excellence in Research for Australia (ERA) project. The process by which the rankings were arrived at was so flawed that the Commonwealth government declared them invalid in 2011, (Note 73) yet most universities still persist in using them in evaluating staff performance - an indicator of how corporatisation has had the inevitable consequence that the tertiary education sector now shares with the business world a fetish with rankings.

\section{Suggested Remedies}

After reviewing the changes to university governance and regulation over the past two decades, it is difficult to identify what the ideology behind the changes was. Indeed, the entire project appears to reflect ideological confusion: Whereas the justification advanced for the corporatisation of university councils was that universities needed to adopt the structures of the business sector in order to compete in the market - which would suggest a neo-liberal ideology - the intrusive regulatory system that has been erected in the years since 2001 is incompatible with a free-market system, and is rather reminiscent of the heavy state control which is characteristic of socialist governments. So the new system is neither neo-liberal nor socialist. One can also say that it is not conservative either - for surely conservatives would hark back to the traditional systems of governance established in the middle ages and which survived until the second half of the $20^{\text {th }}$ century. So what is one left with? There are two possible explanations, equally disturbing: The first is that there is no coherent ideology underlying the policies of successive Commonwealth governments. (Note 74) The other is that what we are dealing with is simply statism (Note 75) - the accumulation of power to the state for its own sake - an ideology which shares with fascism the belief that corporate and government power should be merged, with the former serving the latter, to the cost of institutional autonomy. (Note 76) This has led to a situation where, according to one educational commentator, Australian academics are possibly the most tightly controlled in the Western world. (Note 77)

It is rare for governments, once they have assumed control to surrender it. Therefore it would be naïve as to think that the university re-structuring effected in Australia over the past 20 years can easily or quickly be undone. Nevertheless the necessity for embarking on such a project, and what should be done to achieve it, needs to be stated. Furthermore, although corporatisation and manageralism are worldwide trends, (Note 78) the trend is not uniform. Indeed it has been reversed in France, where in 2013 the new socialist government of President Francois Hollande reversed changes made by the conservative government of Nicolas Sarkozy. The incoming Minister of Education, Geneviève Fioraso criticised the reduction in lecturer and student representatives on university councils, and said it was not possible to organise a university in the same way as a company, also stating that collegiality, which she referred to as 'the true university spirit', needed to be restored. (Note 79) France subsequently enacted a law which increased the size of university councils as well as the proportion of member elected by staff (Note 80) - a move which was opposed by Vice-Chancellors, who feared a reduction in their powers, but was welcomed by academics on the ground that it would reverse the trend towards universities being dominated by managers rather than by staff. (Note 81 )

What then - thinking ideally - should be done? How can we unravel the harms that have occurred and establish governance structures which are consistent with the social function of universities - namely to be genuinely autonomous, self-accrediting institutions dedicated to teaching, research, truth-seeking and truth-speaking?

First, the various State and Territory Acts ought to be amended so as to define the purpose of the institutions they regulate in a manner consistent with the historic social function of a university as summarised in Part 2.4 above. The Acts ought also to reform the structure of university councils in a manner which institutional autonomy. In light of the critique of the current legislation of University Acts contained in Part 4 of this article, a university's governing Act should therefore specify that

- the function of the University is to conduct teaching and research and freely to engage in truth-seeking and the public communication of ideas;

- the University has the sole authority to accredit the courses it offers;

- a majority of the University council must be elected by a combination of the academic staff, administrative staff, students and graduates;

- the council is entrusted with the overall running of the University and

- in the discharge of their duties, councillors must always act in furtherance of the purpose of the University. 
Second, it must be recognised that the Commonwealth's intrusion into the day to day running of universities is incompatible with university independence, and that restoration of that independence therefore requires that:

- the TEQSA Act be repealed and

- the AQF continue in existence as a voluntary framework for universities to use if they wish.

These legislative amendments would not pose no risk to the quality of tertiary education. Legislation which pre-dates the TEQSA regime provides adequate mechanisms for necessary oversight:

Given that universities use public funds, the public has a legitimate interest in ensuring that university finances are being properly deployed, and that is already achieved by financial audit to which universities are subject.

Similarly, the principle that universities should be accountable to students for the quality of the courses they offer - recognised at the very start of the university movement in $11^{\text {th }}$ century Europe - is to some extent already upheld by the complaints mechanisms provided by State Ombusdmen. For example, the New South Wales Ombudsman, acting under the Ombudsman Act 1974 (NSW), has jurisdiction to consider complaints of maladministration on the part of universities. (Note 82) However, it is questionable the concept of maladministration extends to complaints about the quality of courses offered by a university. I would therefore argue that the effectiveness of the ombudsman mechanism as a remedy for students in such circumstances could be enhanced either by creating a specific Universities Ombudsman with the power to investigate such complaints, or by expanding the jurisdiction of State Ombudsmen so as to include them. A suitable model for a specific tertiary sector ombudsman is provided by the Office of the Independent Adjudicator for Students in Higher Education (OIAHE) in the United Kingdom, which has the power to investigate a wide range of matters, including services provided by universities and the standards of teaching and of facilities. (Note 83) Such an approach would mean that shortcomings in quality would be addressed as and when they could be proved, instead of there being a presumption that academics are likely not to discharge their duties properly, and therefore need constantly to be monitored, which is the philosophy underlying the TEQSA Act.

Finally, so far as research is concerned, there is no doubt that the vesting of majority voting power over the composition of university councils in staff, students and graduates would dramatically change research culture, and the current fixation on grant applications as a measure of staff research performance would soon disappear. The only reform relating to research that would require a change in government policy is that textbooks should be counted under the HRDC process for the purposes of funding under the RIBG programme.

The process of reforming Australian universities so that they are once more autonomous communities of academics and students will be long and difficult, but the recent example of France shows that the wheel may turn - even if this means that change comes about in Australia after many years, and only once the damage caused to tertiary education becomes so serious as to imperil the functioning of the entire system.

\section{References}

Allan, J. (2011, June 7). Pessimism and creeping managerialism on the agenda. The Australian. Retrieved from $\mathrm{http} / /$ www.theaustralian.com.au/higher-education/opinion/pessimism-and-creeping-managerialism-the-ord er-of-the-day/story-e6frgcko-1226070970720

Brubacher, J. S., \& Rudy, W. (1976). Higher education in transition (3rd ed.). New York: Harper and Row.

Carrick, D. (Presenter). (2000, November 28). Courting Agitation and Free Speech. The Law Report. ABC Radio National. Retrieved from http://www.abc.net.au/radionational/programs/lawreport/courting-agitation-andfreedom-of-speech $/ 3476652$

Chaplin, M. (1977). Philosophies of higher education, historical and contemporary. In International encyclopedia of higher education (Vol. 7, pp. 3204-3220). San Francisco: Jossey-Bass.

Commonwealth of Australia, Department of Education and Training. (1988). Higher Education: A policy statement. Canberra: Australian Government Publication Service.

Commonwealth of Australia, Department of Education, Science and Training. (2003). Our Universities: Backing Australia's Future. Canberra: Australian Government Printing Service.

Commonwealth of Australia, Department of Education, Employment and Workplace Relations. (2008). Review of Australian Higher Education - Final Report. Canberra: Australian Government Printing Service.

Evans, M. (2004). Killing Thinking - The Death of the Universities. London: Continuum.

Fielden, J. (2008). Global Trends in University Governance. The World Bank: Washington. 
Fuchs, R. E. (1969). Academic Freedom-Its Basic Philosophy, Function and History. In L. Joughin (Ed.), Academic Freedom and Tenure: A Handbook of the American Association of University Professors ( $\mathrm{p}$. 431).

Grove, J. (2013, May 9). Hollande's HE reforms face test. Times Higher Education Supplement. Retrieved from http://www.timeshighereducation.co.uk/news/hollandes-he-reforms-face-test/2003654.fullarticle

Goldsworthy, J. (2008). Research grant mania. Australian Universities Review, 50, 17-24.

Harman, K., \& Tredgold, E. (2007). Changing Patterns of Governance for Australian Universities. Higher Education Research \& Development 26. http://dx.doi.org/10.1080/07294360601166786

Higher Education Management Review Committee. (1995). Report to the Minister for Employment, Education and Training. Canberra: Australian Government Publication Service.

Illing, D. (1999, June 2). Hounded for green counsel. The Australian (p. 37).

Levy, J. (2006). The State after Statism: New State Activities in the Age of Liberalization (p. 469). Cambridge: Harvard University Press.

Marshall, J. (2012, June 7). New minister unveils plans for more 'collegiate' university governance. University Word News. Retrieved from http://www.universityworldnews.com

Mill, J. S. (1991). In J. Grey, \& G. W. Smith (Eds.), On Liberty in Focus. London: Routledge.

Miller, S. (2000). Academic autonomy. In T. Coady (Ed.), Why Universities Matter (pp. 110-131). St Leonard's: Allen \& Unwin.

Musselin, C. (2005). Change or continuity in higher education governance? In I. Bleiklie, \& M. Henkel (Eds.), Governing knowledge (pp. 65-80). Amsterdam: Springer.

Rashdall, H. (1895). The Universities of Europe in the Middle Ages. Oxford: Clarendon Press.

Scott, J. (2006). The Mission of the University: Medieval to Postmodern. Journal of Higher Education, 77, 1. http://dx.doi.org/10.1353/jhe.2006.0007

Richards, C. (1999, April 21). Academic Loses E-mail After Criticising Uni. The Age, p. 7.

Rowbotham, J. (2011, June 1). Carr bows to rank rebellion. The Australian, p. 25.

Schauer, F. (1982). Free Speech: A Philosophical Inquiry. Cambridge: University Press.

Silva, C., \& Armstrong, A. (2009). Evaluation of Corporate Governance Measures: An Application to the Australian Higher Education Sector. Journal of Business Systems, Governance and Ethics, 7, 76-86.

Smolla, R. (1993). Free Speech in an Open Society. New York: Vantage Books.

Saunders, M. (2006, March). The Madness and Malady of Managerlialism. Quadrant, pp. 9-17.

Taylor, S. (Ed.). (2102). 30 Second Politics. Millers Point: Murdoch Books.

Tebutt, D. (1999, May 4). Professor booted off-line. The Australian, p. 46.

Thornton, M. (2005). Universities: The Governance Trap and What To Do About It. Paper presented to the Australian Fabian Society, Melbourne, 16 March 2005. Retrieved from http://www.fabian.org.au/876.asp

Weinberg, A., \& Graham-Smith, G. (2012). Collegiality: Can it survive the corporate university? Social Dynamics, 38, 68-86. http://dx.doi.org/10.1080/02533952.2012.700181

Wieruszowski, H. (1966). The Medieval University. New York: Andrews McMeel Publishing.

\section{Notes}

Note 1. Comprehensive studies of university history are provided by Wieruszowski, H. (1966). The Medieval University, New York :Andrews McMeel Publishing.

Note 2. Rashdall, 17-18

Note 3. Ibid, 6.

Note 4. Ibid, 5.

Note 5. Ibid 17.

Note 6. Wieruszowski, 67-69 and 110. 
Note 7. Rashdall, 11.

Note 8. Ibid, 300-1

Note 9. A specific example being the trend towards governmental control over universities during the period of the rise of the nation-state from 1500-1800, and of course under totalitarian regimes of the $20^{\text {th }}$ century see John C Scott 'The Mission of the University: Medieval to Postmodern' (2006) 77 Journal of Higher Education 1.

Note 10. Wieruszowski 70-1.

Note 11. Ibid, 72.

Note 12. Rashdall, 187.

Note 13. Wieruszowski, 37.

Note 14. Rashdall, 333 and 409.

Note 15. Chaplin, 3208.

Note 16. Brubacher and Rudy, 308.

Note 17. Fuchs, 435.

Note 18. The edition referred to is Mill, J. S. (1991) On Liberty in Focus Grey, J. and Smith, G. W. (eds), London: Routledge.

Note 19. Ibid, 37-41.

Note 20. Ibid, Chapter 2. See also Schauer, 24-9.

Note 21. Smolla, 8.

Note 22. Mill, 37.

Note 23. The only exception to this is the Australian National University, which was established by the Commonwealth Parliament, using its implied power to legislate with regard to national institutions.

Note 24. Commonwealth of Australia, Department of Education and Training. (1988). Higher Education: a policy statement. Canberra: Australian Government Publication Service.

Note 25. Ibid, 102.

Note 26. Ibid 111.

Note 27. Higher Education Management Review Committee. (1995) Report to the Minister for Employment, Education and Training. Canberra: Australian Government Publication Service.

Note 28. Ibid 45.

Note 29. Ibid 46.

Note 30. Ibid 47.

Note 31. Ibid 51.

Note 32. Commonwealth of Australia, Department of Education, Science and Training. (2003). Our Universities: Backing Australia's Future. Canberra: Australian Government Printing Service. The report is available at http://www.voced.edu.au/content/ngv38781

Note 33. Ibid 15.

Note 34. Ibid.

Note 35. Ibid 16.

Note 36. Ibid 46-7.

Note 37. For an overview of the history of the changes to university governance in Australia see Silva and Armstrong.

Note 38. For a critique of the use of the corporate governance model as a structure for university governance see Harman and Tredgold, at 13-16.

Note 39. See Musselin at 70. 
Note 40. Usually the Chancellor (who is the figurehead of the university), the Vice-Chancellor (who is the chief executive appointed by the council) and the head of the university's academic board or senate, to which the council delegates control over academic matters.

Note 41. See, for example, s 8B of the University of New South Wales Act 1989 (NSW).

Note 42. See for example, s 11 of the University of Melbourne Act 2009 (Vic).

Note 43. See, for example, s 11(1) of the University of Canberra Act 1989 (ACT).

Note 44. See, for example, s 5(3) of the Flinders University of South Australia Act 1966 (SA).

Note 45. Section 12(1) of the University of Adelaide Act 1971 (SA).

Note 46. Thornton, M. (2005). Universities: The Governance Trap and What To Do About It. Paper presented to the Australian Fabian Society, Melbourne, 16 March 2005. Retrieved from http://www.fabian.org.au/876.asp

Note 47. The document is accessible on the Universities Australia website at http://www.universitiesaustralia. edu.au/resources/684/1328. The recommendation that university councillors be bound by the same duties as apply to company directors is found in item 3 of the Code.

Note 48. Thornton.

Note 49. Wienberg and Graham-Smith, 72.

Note 50. Saunders, 11.

Note 51. Wienberg and Graham Smith, 72.

Note 52. Victoria University of Technology is now named Victoria University. It no longer has elected staff representatives on council - see s 11 of the Victoria University Act 2010 (Vic).

Note 53. Richards, C. (21 April 1999). Academic Loses E-mail After Criticising Uni. The Age, p. 7.

Note 54. Tebutt, D. (4 May 1999). Professor booted off-line. The Australian, p. 46.

Note 55. To take a random example, see s 26A(2) of the University of Queensland Act 1998 (Qld), which adopts the wording of the provisions of the Corporations Act 2001 (Cth) almost verbatim.

Note 56. For an excellent discussion on the negative impact of reform to the tertiary sector on academic freedom see Miller, S. (2000). Academic autonomy in Coady, T. (ed) Why Universities Matter. St Leonard's: Allen \& Unwin, pp. 110-131.

Note 57. Illing, D. (2 June 1999). Hounded for green counsel. The Australian, p. 37.

Note 58. Carrick, D. (Presenter). (28 November 2000) Courting Agitation and Free Speech. The Law Report. ABC Radio National. Retrieved from http://www.abc.net.au/radionational/programs/lawreport/courting-agitation -and-freedom-of-speech/3476652.

Note 59. Commonwealth of Australia, Department of Education, Employment and Workplace Relations. (2008). Review of Australian Higher Education - Final Report. Canberra: Australian Government Printing Service.

Note 60. Ibid 117.

Note 61. Ibid 115-37.

Note 62. Ibid 7.

Note 63. The AQF standards can be found at http://www.aqf.edu.au/aqf/in-detail/aqf-qualifications/

Note 64. Weinberg and Graham-Smith, 74.

Note 65. For an excellent description of how similar bureaucratisation has taken hold in the United Kingdom see Evans, M. (2004). Killing Thinking - The Death of the Universities. London: Continuum, particularly the chapter entitled 'The Heart of Darkness: Audit and Compliance'.

Note 66. Weinberg and Graham Smith, 69.

Note 67. Saunders, 12.

Note 68. This point is well made in Allan, J. (7 June 2011). Pessimism and creeping managerialism on the agenda. The Australian. Retrieved from http://www.theaustralian.com.au/higher-education/opinion/pessimismand-creeping-managerialism-the-order-of-the-day/story-e6frgcko-1226070970720

Note 69. See the ARC's statistics at http://www.arc.gov.au/ncgp/dp/DP12_selrpt.htm 
Note 70. For an excellent overview of the effect of the grant mentality on legal research see Goldsworthy, J. (2008). Research grant mania. Australian Universities Review 50, 17-24.

Note 71. The Specifications for what counts as a publication under the HERDC can be found at http://www.inno vation.gov.au/research/ResearchBlockGrants/Pages/HigherEducationResearchDataCollection.aspx

Note 72. The RIBG scheme is explained at http://www.innovation.gov.au/Research/ResearchBlockGrants/Pages/ ResearchInfrastructureBlockGrantsScheme.aspx

Note 73. Rowbotham, J. (1 June 2011). Carr bows to rank rebellion. The Australian, p. 25.

Note 74. As discussed in Part 4.1, in 2008 the Labor government repealed of those parts of the Higher Education Support Act 2003 (Cth) which had made funding conditional on universities complying with the National Governance Protocols. However, that government did not reverse the changes by requiring State Parliaments to amend their University Acts so as to revert to the status quo ante (Which it could have done, using the s 51(xx) corporations power). This minor amendment aside, neither Labor nor Coalition governments have changed the direction set by each other's legislation regarding university governance and regulation.

Note 75. Levy, 469.

Note 76. Taylor, S. (ed) (2102). 30 Second Politics. Millers Point: Murdoch Books.

Note 77. Saunders, 10.

Note 78. Fielden, 37-8.

Note 79. Marshall, J. (7 June 2012). New minister unveils plans for more 'collegiate' university governance. University Word News. Retrieved from http://www.universityworldnews.com

Note 80. Loi à l'Enseignement Supérieur et à la Recherche No 180, 9 July 2013. Retrieved from $\mathrm{http}: / / \mathrm{www}$.assemblee-nationale.fr/14/ta/ta0180.asp

Note 81. Grove, J. (9 May 2013). Hollande's HE reforms face test. Times Higher Education Supplement. Retrieved from http://www.timeshighereducation.co.uk/news/hollandes-he-reforms-face-test/2003654.fullarticle

Note 82. See the Ombusdman's website at http://www.ombo.nsw.gov.au/what-we-do/our-work/universities

Note 83 . See the OIA website at http://www.oiahe.org.uk

\section{Copyrights}

Copyright for this article is retained by the author(s), with first publication rights granted to the journal.

This is an open-access article distributed under the terms and conditions of the Creative Commons Attribution license (http://creativecommons.org/licenses/by/3.0/). 